\title{
The costs of organized violence: a review of the evidence
}

\author{
Stergios Skaperdas
}

Received: 5 March 2010 / Accepted: 2 July 2010 / Published online: 23 July 2010

(C) The Author(s) 2010. This article is published with open access at Springerlink.com

\begin{abstract}
I critically review recent studies that estimate those costs of violence and conflict that can emerge among organized political groupings, such as states, religious and ethnic organizations, guerillas and paramilitaries. The review includes studies that estimate direct and indirect costs due to internal conflicts (civil wars and other lower-level conflicts), terrorism, and external conflicts, including military spending. There are a number of key theoretical concerns on what counts as a cost, and, depending on the methods and evidence used, estimated costs vary widely. However, even minimum estimates are economically significant, especially for low-income countries. This is even more so when the costs of different types of organized conflict and violence are aggregated.
\end{abstract}

Keywords Conflict · Property rights · Governance

JEL Classification $\quad \mathrm{D} 74 \cdot \mathrm{H} 56 \cdot \mathrm{I} 31 \cdot \mathrm{O} 57$

\section{Introduction}

Violence can occur at virtually all levels of human interaction-from domestic violence within households, to fighting between youth gangs, to guerilla warfare, to wars between states or between alliances of states. Although all forms of conflict and violence can be expected to have economic consequences, this aspect has been neglected by economists until relatively recently. However, research in this area has accelerated in the past decade as it has become increasingly evident to academics and policymakers that wars and other conflicts have high costs that can

S. Skaperdas $(\varangle)$

Department of Economics, University of California, Irvine, CA, USA

e-mail: sskaperd@uci.edu 
severely impede economic development. In this paper I review recent studies that estimate the costs of violence and conflict that can emerge between organized political groupings such as states, religious and ethnic organizations, political parties, unions, guerillas, or paramilitaries. In particular, I examine the costs associated with:

- Internal conflicts: More than 70 countries have experienced civil war since World War II (Fearon and Laitin 2003). The median length of a civil war is more than 7 years and the costs include the loss of life (at least 16 million in such wars); the destruction of crops, buildings, and infrastructure; the cost of arms; the wages or opportunity cost of soldiers or guerrillas; the cost of injuries and psychological incapacitation (which can be long-lasting); as well as long-term consequences on investment and economic growth.

Civil war is not the sole form of violent conflict that can occur within countries. Lower-level insurgencies, as well as protests, strikes, boycotts, road-blocks, and similar "appropriative" activities that are undertaken by well-organized groups can lead to violence. We will touch upon these lower-level types of conflict, although there is less evidence on them than there is for civil wars.

- Terrorism: In some cases, violence is directed at civilians who may not even be related to the political target of the perpetrating group, resulting in what has come to be referred to as terrorism. Properly speaking, terrorism is a tactic that is usually part of a larger conflict that can be internal to a country (like in Sri Lanka or Spain's Basque region) or transnational in scope (like that of al Qaeda). We review the costs of it separately from internal and external conflicts primarily because some of the recent literature on the costs of violence and conflict has focused on terrorism.

- External conflicts: Although external wars between states have been fewer and caused less direct damage than internal wars since World War II, they have remained very costly for some countries (for example, Afghanistan and Vietnam) that have been involved in such warfare. Despite the relative paucity of such wars, perceived external threats induce considerable military expenditures. For 2004 world military spending was estimated to be over 1 trillion dollars, about 2.6 percent of world gross domestic product (GDP) (SIPRI 2005), a considerable expenditure by any measure.

Excluded from this review are the costs of organized crime, a global activity in which the threat and use of violence are integral. Journalistic reports even argue that organized crime accounts for one-fifth of world GDP (Glenny 2008). However, to my knowledge there are very few systematic economic studies that estimate the costs of violence due to organized crime and this is the main reason for excluding them here. $^{1}$

Studying the effects of conflict and violence from an economic perspective is perhaps more difficult than studying the effects of ordinary economic activities. This is because the basic theoretical framework of economics-and, as a result, much

\footnotetext{
1 A recent study (Asmundo and Lisciandra 2008) provides a lower bound estimate for the cost of protection in Sicily to be 1.4 percent of gross regional product. However, this is mostly an estimate of transfer costs (the protection payments) rather than the net economic costs of the Sicilian Mafia. Skaperdas (2001) provides an overview of the economics of organized crime.
} 
empirical research-assumes that property rights are perfectly and costlessly enforced. Conflict and violence directly contradict this assumption. Furthermore, engaging in conflict and violence against others is an adversarial activity, not a socially cooperative or productive one, as economic activities typically are. (For an overview of the theoretical literature on conflict that formally examines these issues, see Garfinkel and Skaperdas 2007.) Identifying what is a cost (and what is a benefit) of conflict, then, can be confusing and potentially controversial. However, regardless of method, even the minimum estimated costs of conflict and violence appear to be higher than estimated deadweight costs that are typically of major concern to economists (such as the effects of taxation, regulation, or trade protection) and therefore potentially of higher economic significance than the effects of more exhaustively studied distortions.

The costs of violence and conflict are not just those incurred directly when there is overt violence. Efforts to prevent overt violence from occurring, as during cold wars or in the low-level suppression of insurgencies, racks up economic costs as well. Consider that most military equipment and many soldiers have never faced or will never face war, yet still need to be purchased or paid. Moreover, the potential for conflict, even if it never materializes, can have powerful negative incentive effects on investment, trade, and economic growth. (Garfinkel and Skaperdas 2007, and Gonzalez 2010, develop theoretical models that take account of the various negative economic effects of conflict.) Though difficult to identify, some of the studies we review attempt to capture these negative effects of conflict potential that may never materialize.

Section 2 of this paper briefly discusses the types of costs we review and the methods used to measure and estimate them. Section 3 reviews the estimates of different types of costs associated with civil war, other forms of internal conflict, terrorism, and external wars. Coverage of the expanding literature is not meant to be comprehensive: Instead, I selectively review contributions from the different categories of costs that have been examined. The final section identifies potential gaps of the costs that might not be adequately taken into account.

\section{Methods of measurement and types of costs}

The cost to replace a house that has been destroyed during warfare, and the loss of the benefit of its services, can be calculated relatively easily. The cost of lost tourism in a volatile region, or the effects of post traumatic stress disorder (PTSD) on its residents, however, are less easy to estimate and depend in part on the method of measurement and empirical model employed by the researcher. The range of probable values of such costs can then vary widely. In this way, a continuum of possibilities exists when estimating the costs of violence, from considering only the most direct costs that have an easily calculable value to estimating different indirect costs. These further depend on what channels of causality, scenarios, and counterfactuals are assumed or which models are estimated.

The methods to estimate costs that have been used in the literature reviewed here, as well as the types of costs that have been estimated, are now briefly discussed. 
2.1 Direct costs: accounting within and outside budgets

The costs that can be directly attributed to a violent event (or a series of such events, as in a war) can be in principle counted using conventional accounting methods. Some of these direct costs typically include the following:

- destroyed public infrastructure

- destroyed factories and machinery

- destroyed housing, autos, and other personal property

- budgetary appropriations for cost of war and cost of lost equipment

- deaths

- physical and mental injuries

- future costs of disability

- future costs of physical and mental health care

Information on some of these costs can be easily obtained or inferred from government budgets or estimated using straightforward methods. Other direct costs, however, can be more difficult to calculate. Even some costs that are part of a government's war budget can be hidden in items that are not related to any particular defense expenditure, let alone part of a particular appropriation for a war. For example, many of the expenditures of the Iraq and Afghanistan wars are not to be found in the appropriation bills for these wars, but elsewhere in the US budget (Bilmes and Stiglitz 2006; Stiglitz and Bilmes 2008).

Accounting for the costs of deaths and injuries also goes beyond the costs included in some budgets (such as the death and life insurance benefit for soldiers that might be provided by their country). Such accounting requires confronting the issue of the value of life and, even more seriously, whether the life of a citizen of a poor country should be valued differently than the life of a citizen of a rich country. Other questions regarding some difficult-to-measure direct costs include: How do you account for the pain and suffering of the physically and mentally injured? What about the lost wages and other missed opportunities of family members who have to care for the long-term disabled? Moreover, since a substantial portion of these costs will be incurred in the future, calculating their present value requires not just estimates of their future trajectory but also assumptions about the discount rate that is employed in such calculations.

\subsection{Indirect costs}

Indirect costs of violence and conflict typically include:

- population displacement

- reduced production due to violence or its threat

- reduced trade due to violence or its threat

- lower current and future physical investment

- reduction in educational opportunities

- brain drain (that is, emigration of educated work force)

- reduced tourism from abroad

- other macroeconomic effects (inflation, further unemployment, reduced economic growth)

- overall welfare costs 
Simply using an accounting method does not suffice in the estimation of such costs. The use of counterfactual worlds in which conflict is absent, models of such worlds, econometric estimation, quasi-experimental methods, and combination of these methods have been used in estimating indirect costs of conflict. We briefly outline two main classes of these methods next. (A much more detailed account of the different methods used is Gardeazabal 2010.)

\subsubsection{Estimating indirect costs under different scenarios}

A simple way of estimating some indirect costs is to create scenarios in the absence of conflict and, based on previous empirical estimates of parameters under similar scenarios, make comparisons between the "conflict" and "nonconflict" scenarios.

A simple example of how some indirect effects might be estimated is found in the long-run effects of budgetary expenditures through "multiplier" effects. The cost of war expenditures on foreign soil, for instance, may not involve just its opportunity cost in other types of expenditures but may well lead to lower multiplier effects because a significant portion of the expenditures "leak" outside the country (see Stiglitz and Bilmes 2008 on the costs of the Iraq war). In a very different context, Evia et al. (2008) estimate some indirect costs of sociopolitical conflict in Bolivia by assigning different disruption coefficients to different incidents (for example, road blockades, strikes, lockouts) in estimating such indirect costs of conflict for the economy. ${ }^{2}$

The advantage of such methods is that they are rather easy to perform and, if previous estimates of key parameters are reliable, the obtained estimates of costs can be plausible, at least as a first approximation. The disadvantage is that such estimates might take inadequate account of general equilibrium interactions and complex effects that cannot be detected through simple scenario calculations. However, these estimates are usually taken as rough, with wide bounds for probable range of values typically provided.

\subsubsection{Estimating indirect costs via regressions}

With appropriate data, counterfactual scenarios could be estimated and tested econometrically. For instance, in a cross-country growth regression that includes a variable for a particular type of conflict, one could compare the differential effects of that conflict on growth by calculating the effect of the conflict variable in the estimated equation. ${ }^{3}$ As an example of that approach, Collier (1999) employed such an approach for a sample of 92 countries (19 of which had civil wars), using as the dependent

\footnotetext{
2 A strike, for example, was assumed to induce 2.77 times the estimated direct economic losses of the event because of the potential disruption to related industries. The activity with the greatest disruption multiplier assumed (12.5 times its estimated direct economic cost) was an urban blockade. Due to the population density in cities, it was estimated that every individual participating in an urban blockade affects 100 more individuals, but not for the same amount of time of the blockade, since people have other options to move around. The study assigned $1 \mathrm{~h}$ loss per individual suffering a blockade in the city. This is $1 / 8$ of a labor day, so that the final effect was $100 * 1 / 8=12.5$ (see Appendix A in Evia et al. 2008).

3 Of course, such an exercise would be subject to critiques aimed at cross-country growth regressions in general, as well as on how the particular regression has been implemented.
} 
variable the decade average of per capita GDP between 1960 and 1989. As one measure of the level of conflict, Collier used the number of months that each country had been in civil war during the decade. In addition to control variables, Collier also used a variable for postwar recovery and its interaction with the months-of-war variable. Blomberg et al. (2004) offer another example that employed a similar approach using many different data sources for a large number of countries, with four different types of conflict, ${ }^{4}$ and in addition to cross-country and panel regressions used vector autoregression (VAR) methods to identify possible causal directions and the economic costs of different types of conflict. In this case, the inclusion of different types of conflict allows for the detection of possible complementarities between different types of conflict; for example, terrorism and certain types of internal ethnic conflict could be complements and the analysis might tease out which effect is more important.

Given the econometric estimates, the effects of various types of conflict could be calculated by considering a "counterfactual" country or region that has the same characteristics as the country or region in question, but without conflict. Of course, such approaches can be criticized on many grounds. ${ }^{5}$ The most fundamental problem is typically the possible endogeneity of conflict when estimating its costs and effects on investment, growth, capital flight, tourism, and so on, and therefore there is the possibility that the causality could be reverse from that assumed. After all, low or negative growth can cause conflict (Miguel et al. 2004). Different studies attempt to overcome this problem by using Instrumental Variables, but some healthy skepticism is warranted in considering such estimates, just as in the case of the scenario-based estimates of indirect costs. The further one moves from easily measurable direct costs, the more uncertain and subject to argument are the estimates of many indirect costs.

\section{Reviewing the findings on the costs of conflict}

In reviewing the findings I will break down the literature into four categories: Civil wars, lower-level internal conflicts, terrorism, and external wars. As civil wars have been most studied, and their effects have been the costliest and most wide-ranging for low-income countries, I will discuss civil wars in terms of the different categories of costs examined in the literature.

\subsection{Internal conflicts: civil wars}

Civil wars are typically defined as those types of internal conflict that involve the government and at least one other party. They also feature a threshold of deathstypically, 1,000 per year. ${ }^{6}$ Collier et al. (2003) provide a comprehensive discussion of

\footnotetext{
4 The four types of conflict are terrorism, internal wars, external wars away from home territory, and external wars at home.

5 See, for example, the critique of Blomberg et al. (2004) by Garfinkel and Jeliazkov (2004).

6 However, there are considerable issues of concern in the definitions that are employed in data sources. The different thresholds for deaths and the classification of a war as internal (instead of, say, colonial) are two of the main concerns. Sambanis (2004) provides a detailed account of the issues and the empirical consequences of using different definitions of civil war.
} 
the different types of costs associated with civil wars and offer an overview of different quantitative estimates. The two edited volumes by Stewart and Fitzgerald (2001) also contain a number of country studies and overall evaluation of the effects of war on economic development. Two recent overviews are Blattman and Miguel (2010), a survey of the theory, causes, and consequences of civil wars, and Collier et al. (2008), a policy-oriented piece that includes estimates of the costs of civil wars. We provide a breakdown of the different types of costs and report some of the findings from these and other recent studies.

\subsubsection{Budgetary costs}

As reported in Collier et al. (2003), the average developing country in 1995 (one with less than $\$ 3,000$ per capita GDP) increased its military expenditures during civil wars from 2.8 to 5 percent of GDP. ${ }^{7}$ That is, before accounting for other direct and indirect costs, on average the extra cost of military expenditures due to civil wars is 2.2 percent of GDP. Furthermore, other government revenues and expenditures_-and, therefore, the public goods they supply-tend to decrease with the length of the war. In a sample of six countries, for example, Fitzgerald et al. (2001) report that tax revenues during war decreased or remained flat relative to GDP in five (Mozambique, Sierra Leone, Sri Lanka, Sudan, and Uganda) and increased in only one (Nicaragua). Then, reductions in the fiscal capacity of states to provide for public goods such as basic health care and other social services induces various indirect effects on the population to withstand disease, injury, malnutrition, and poverty.

\subsubsection{Destruction of capital, investment, and capital flight}

Infrastructure-roads, bridges, railroads, public buildings, hospitals—are often at the center of fighting between rebels and governments. Private capital, such as factories and housing and cattle are also often subject to significant destruction. There are currently no studies that systematically quantify these costs and compare them across countries, but in nations that have experienced long wars, these costs are high. For Mozambique, which experienced war continually from 1964 to the early 1990s, Bruck (2001) has made the following estimates: From 1980 to 1993 the stock of cattle had decreased 20 percent; from 1983 to 1991 almost 60 percent of primary schools were closed or destroyed; and overall, 40 percent of immobile capital was nonoperational and destroyed. For Nicaragua, Fitzgerald and Grigsby (2001) have estimated that, over the years of most intense conflict (1987-1989), the cumulative total economic damages were equal to about one year's GDP.

\footnotetext{
7 There is no direct reference on how these figures were calculated, but it appears they were derived by using the estimated coefficients for a cross-country type regression. Additionally, note that a higher percentage of GDP devoted to military expenditures could, in principle, result from a sufficiently precipitous drop in GDP without a change in actual defense expenditures. However, the reduction in per capita GDP due to civil war was estimated to be on the order of 2 percent by Collier (1999) and growth rates for a country in civil war are not typically negative. Therefore, the increases in military expenditures cannot be due to decreases in GDP alone.
} 
Collier et al. (2003) also reports estimates of capital flight for countries in civil war. In these, the share of private wealth held abroad goes from 9 percent before the war to 20 percent by its end. Moreover, as far as capital is concerned, war according to Collier et al. has lasting effects - by the end of first decade of post-conflict peace, capital flight rises to 26.1 percent. However, as mentioned in the following section on terrorism, Blomberg et al. (2004) find neither a statistically or economically significant effect of internal conflict on investment.

\subsubsection{Effects on growth}

According to Collier (1999) estimates, countries at war grow around 2.2 percentage points more slowly than during peace. Long-lasting wars tend to induce lower levels of growth. Stewart et al. (2001) calculate the difference in growth rates for 14 countries at war and compare them with those of similar countries. They found them lagging on average about 3.4 percentage points in GDP. ${ }^{8}$ More recently, Cerra and Saxena (2008) estimate the effect of civil wars on economic growth using the beginning of civil war as a shock in a VAR model. Using impulse response functions, the immediate effect of a civil war is estimated to induce a reduction of 6 percentage points in GDP, although almost half of that loss is recovered after about 6 years, and the long-run estimates are imprecise in the sense that the standard error bands allow for the possibility of a zero long-run effect. In the event of a long civil war, these negative effects on growth can be expected to compound over time and it is not clear to what extent output can be expected to partially recover in the long run, as it does in the impulse response to a theoretical one-time shock.

Country experiences in terms of growth of course vary widely. Afghanistan's GDP per capita fell by 20 percent from 1980 to 1990 and by 7.5 percent per year from 1990 to 1995 (Mardsen and Samman 2001). Sri Lanka, on the other hand, has experienced robust growth rates during war. In fact, according to O'Sullivan (2001), Sri Lanka experienced a 4.4 percent GDP growth rate during war and only 3.2 percent in the absence of war. One possible reason for such a performance was the geographical concentration of war in the Tamil areas of the island that left the rest of the country relatively unaffected. Speaking of regional differences, Miguel and Roland (2006) exploit the regional variation of the air bombing campaign of the US in Vietnam in order to estimate long-run effects of conflict. They find that areas that suffered heavy bombing did not suffer a long-run negative impact on poverty rates, consumption levels, infrastructure, or literacy. It could be that this finding is due to the absence of long-run effects from bombing. Nevertheless, it is also likely that the Vietnamese government directed more resources towards the areas that were heavily bombedthey may have built more modern infrastructure that enhanced the growth potential of these areas over those that were not as heavily bombed, and thus retained their older infrastructure. In addition, Vietnam has been a rather poor country in terms of absolute levels of income since the war ended, and the war likely had an effect on its

\footnotetext{
${ }^{8}$ However, the sample includes Iran and Iraq which were engaged in external war during part of the sample period, with Iraq experiencing the worst performance of all 14 countries in the sample.
} 
growth rate. The possible diversion of resources to the more heavily bombed areas likely reduced the country's overall growth rate.

Another long-term effect of civil war according to Collier et al. (2003) is that military expenditures increase permanently, on average, to 4.5 percent of GDP, instead of reverting to 2.8 percent. That implies a long-term substitution of 1.7 percentage points of GDP that become unavailable for civilian investment, other public expenditures, and consumption. This comes in addition to the possible permanent reduction in income induced by civil war.

\subsubsection{Mortality and health}

A conservative estimate of the deaths directly attributable to civil war between 1945 and 1999 is 16.2 million (Fearon and Laitin 2003). The World Health Organization (WHO) estimates that in 1999, wars directly caused 269,000 deaths (Ghobarah et al. 2003), a number that is a bit lower than in previous years. The International Rescue Committee estimates that 5.4 million people have died from war-related causes in the Democratic Republic of Congo since 1998 alone. ${ }^{9}$

For public policy purposes, the cost of death in rich countries is usually monetized using estimates of the value of life. For example, to estimate the cost of US soldiers' deaths, Stiglitz and Bilmes (2008) use \$7.2 million as the Value of Statistical Life (VSL), which is consistent with recent usage. However, Stiglitz and Bilmes did not think it was appropriate to use a different figure to estimate the cost of death for Iraqis. But making rough estimates might help to gain a sense of what the cost of death in low-income countries might be. For instance, if we were to value the life of a citizen of the Democratic Republic of Congo at 1/72 of that of an American citizen (that is, $\$ 100,000$ ), the total cost would be $\$ 540$ billion over the past 10 years (for comparison, the CIA World Factbook estimated the GDP of the country in 2007 to be a little over $\$ 19$ billion at purchasing power parity). Even if the value of life in the Democratic Republic of Congo were considered at $1 / 720$ of an American life $(\$ 10,000)$, still the cost would be $\$ 54$ billion. What such numbers indicate is that no matter how one views the loss of life in civil wars, these losses pose an immense cost to both the deceased's loved ones and their country.

One persistent source of death and injury that lasts beyond the length of a war is landmines. The International Campaign to Ban Landmines estimated the total number of such casualties to be between 15,000 and 20,000 in 2001 (Collier et al. 2003). Such figures represent a significant improvement from previous years, when casualties from landmines were estimated to be around 26,000 per year. This reduction is attributed to the 1997 international ban on antipersonnel mines. Landmines can also have serious economic consequences. Not only may injured farmers be unable to work, but land that is suspected to be populated with mines can be underutilized or abandoned, further contributing to the affected population's poverty. Merrouche (2008) offers a case study of the effect of landmines in Mozambique, one of the most heavily mined countries in the world. The study finds that going from an average number of landmines to none

\footnotetext{
9 http://www.theirc.org/special-report/congo-forgotten-crisis.html.
} 
is associated with an 11 point decrease in the fraction of impoverished people and a 27 percent increase in daily consumption.

Beyond mortality and injury, civilian populations plagued by war become highly vulnerable to disease as a result of worse nutrition, living conditions in camps, or deteriorating health care. Malaria, diarrhea, respiratory infections, AIDS, even measles and meningitis occur more frequently during wartime and result in higher death rates than in times of peace (Collier et al. 2003). Measures exist for aggregating the impact of different diseases, such as disability-adjusted life years (DALYs). ${ }^{10}$ For 1999 alone, 8.44 million DALYs were directly attributed to wars (Ghobarah et al. 2003). Moreover, during the same year an additional 8 million DALYs were lost as a result of wars that ended in the years 1991-1997. In principle, one could use such estimates, along with their value in terms of prevailing wages and estimates for pain and suffering, to arrive at dollar estimates of the cost of disease.

\subsubsection{Population displacement and emigration}

Another direct effect of civil war is displacement. The number of refugees around the world peaked at over 17 million in 1992, but has barely fallen below 10 million since then (United Nations High Commission for Refugees (UNHCR) 2007). However, by the end of 2006, the number of UNHCR "persons of concern" (which includes refugees, and Internally Displaced Persons (IDPs), and others) reached 32.9 million, whereas it hovered around 20 million for the preceding decade. IDPs rose most in 2006. Displaced persons and refugees are often unable to find work, and also need to be fed and housed. Thus, an accounting of the costs of population displacement should include both the cost of their care and at least a partial measure of the opportunity cost of the population.

\subsubsection{Psychological effects and community life}

Evidence from case studies suggests that the psychological effects of civil war are significant and long lasting. For example, as cited in Collier et al. (2003), "approximately $68 \%$ of the Cambodia refugees on the Thai border displayed symptoms of major depression and $37 \%$ showed symptoms associated with posttraumatic stress disorder (PTSD)." Community life under such conditions can be expected to suffer. "Social capital," according to Collier et al. (2003, p. 21), is lost: "Civil war can have the effect of switching behavior from an equilibrium in which there is an expectation of honesty to one in which there is an expectation of corruption."

However, the evidence on how civil war affects the psychology of war participants, victims, and community life is not completely one-sided. Bellows and Miguel (2008) have used household data on conflict experiences and postwar outcomes to examine the effects of the 1991-2002 civil war in Sierra Leone. They found those who expe-

\footnotetext{
10 According to the World Health Organization, "DALYs for a disease are the sum of the years of life lost due to premature mortality (YLL) in the population and the years lost due to disability (YLD) for incident cases of the health condition." Further details on how DALYs are calculated are found at http://www.who. int/healthinfo/boddaly/en/.
} 
rienced increased violence are 2.6 percent more likely to vote and 6.5 percent more likely to attend community meetings and contribute to public goods. "Civil war experiences are transformative for many, and our analysis suggests that one short-run legacy is increasing individual political participation, community activism, and local public good provision." 11 However, the sample is highly localized so that no general inference can be made about the whole country. Blattman (2008) also finds that forcibly conscripted soldiers in Uganda actually increased their political participation compared to a control group. These two studies raise the possibility that at least some individuals in some cultures might be psychologically resilient to being victims of violence in ways that make them, if they survive, more determined to participate socially and politically in their communities.

Although many of the costs we have already mentioned are difficult to estimate, there are still others that are so difficult to estimate it is almost impossible to monetize them, and thus they are unable to be compared with the other costs. For example, the very old, the very young, the infirm, and the poorest are more vulnerable to the direct and indirect effects of civil wars and are therefore more likely to suffer. In other words, civil wars appear to disproportionately affect the poor and most vulnerable members of society. Studies like those of Merrouche (2008) do provide estimates of specific effects on poverty (landmines, in this case). Yet quantifying this effect beyond the reduction of income for those involved is a matter of debate. Aggregate estimates of the increased risk of mortality and morbidity could identify some of the costs of poverty and vulnerability. However, the value of less poverty in itself, or the possible higher value of an extra dollar to a poor versus a rich person are issues that have been, and will likely continue to be, debated within the economics and policy communities. Justino (2006, 2010) provide summaries of research and discusses the methodological issues concerning both the effects of war on poverty and how chronic poverty might induce war.

Collier et al. (2008) have ventured to make some overall estimates of the costs incurred by civil war. Counting only the direct costs for an average low-income country, as well as those imposed on its neighbors as a result of the war, the estimated total cost is $\$ 43$ billion. ${ }^{12}$ Adding estimates for the costs of death and DALYs yield a total minimum cost of almost $\$ 60$ billion for a single civil war. Based on that estimate and the number of civil wars that have taken place since 1960, the yearly cost of civil war is estimated to be $\$ 123$ billion, which is about the same order of magnitude as the total annual development aid. Collier et al. (2008), however, think that a better estimate of the indirect costs of a typical civil war is not $\$ 60$ billion but closer to $\$ 250$ billion. That is, according to their estimates, the minimum cost of civil wars equals all the development aid provided, but is likely to be much higher than that.

\footnotetext{
11 Bellows and Miguel 2008.

12 The costs to neighbors (\$23 billion) are actually higher than those to the country itself (\$20 billion). (There is no description in the paper of the methods used to arrive at the costs for the country itself.) The estimates of the cost to neighbors use the results from Murdoch and Sandler (2002) that are based on an estimated growth model that allows for such spillover effects.
} 


\subsection{Lower-level internal conflicts}

Civil wars, by the most common definition, result in more than 1,000 deaths. Conflicts with lower death tolls that are not formally classified as civil wars, however, can have high long-term indirect costs as well. Moreover, other lower-level conflicts between organized groups can involve violence or, even if there is no direct violence, the possibility of violence is ever present. Strikes, road blockades, or protests that might have economic, ethnic, or regional motivation, or disputes between organized prospective squatters and landowners are examples of common conflicts. As is the case with the other types of conflict we examine, these too involve direct and indirect costs. However, there is rarely destruction of property, few direct deaths or injuries, and typically related actions are dispersed geographically, even if frequent and economically disruptive. As a result, there is little standardized information (or, "data") that is systematically gathered so that even the most direct costs of such conflicts can be assessed. Their long-term indirect effects, though, could be as economically disruptive as those of civil wars.

Evia et al. (2008) use data on different incidents (strikes, road blockades, protest) from Bolivia between 1970 and 2005. The time cost alone of the participants in such incidents was on the order of 1 percent of GDP. Such incidents can also have significant spillover effects on the economy. A strike in a manufacturing plant, for example, can affect the output of other downstream and upstream production. Similarly, a road blockade can bring about wide-ranging disruption in the affected city or region. On the other hand, a sit-in or protest with few participants does not have much of an effect on economic activity. Based on assumptions of different multipliers regarding the spillover effects of different incidents, the average yearly cost of spillovers was estimated to be more than 3 percent of GDP. These costs varied widely over the years and were much higher for the mid-1980s and the 2002-2005 period, with some years approaching a loss of as much as a tenth of GDP.

Riascos and Vargas (2004) summarize results of research that includes the costs of common crime and other conflict in Colombia. They estimate these to be at least 3 percent of GDP, with some estimates going as high as 15 percent. Note that a 3 percent annual cost of conflict implies that after 24 years, a country would have 50 percent less income than it would otherwise obtain in the absence of such conflict.

\subsection{Terrorism}

One definition of terrorism is the use of violence against civilians by organized groups. ${ }^{13}$ Since it is a tactic in the conduct of violence, it can and has been used

\footnotetext{
13 Often it is specified that terrorist violence has a political purpose. Whereas in the large majority of cases political purpose is a feature of what is called terrorism, there are some cases in which it does not have to be so. For example, mafias and gangs can engage in terrorism in order to expand their turf and profits, and there is no scientific or policy reason for excluding in principle such activity from the definition of terrorism. Sometimes actions of organized crime groups might even take political dimensions, even though the clarity of that dimension might be murky. For example, Pablo Escobar, of the Colombian Medellin cartel, made a clear bid for political power by employing actions against civilians that could be considered terrorism.
} 
in civil wars, other internal conflicts, and even in international disputes. The disproportionately large number of civilian casualties (compared to previous wars) during the Second World War and wars since could be attributed to such a tactic (and the technology that made such tactics possible). However, the data and the related empirical literature focus on the activities of organized groups that are often, but not always, militarily weak in other ways, and thus employ terrorism as a primary tactic. For example, almost all instances of systematic mutilation or raping of civilians (which can have a political purpose from the perpetrator's viewpoint) that have occurred in many post-World War II civil wars, especially those that have occurred in Africa, are not typically included in the data used in studies of terrorism.

A main distinction is made between terrorism committed for domestic purposes, such as the actions of the Tamil Tigers in Sri Lanka or Euskadi Ta Askatasuna (ETA) in Spain, and terrorism committed for transnational purposes, like those of al Qaeda. Two recent overviews of the costs of terrorism are Enders (2007), Sandler and Enders (2008).

With the exception of major incidents like those of 9/11 and the Madrid bombings, the direct costs of individual terrorist incidents are usually not large. Even the direct cost of $9 / 11$ has not been large relative to GDP. ${ }^{14}$ Therefore, the main effects that could exist, if any, would be indirect, confined to perceptions of security and their effect on investment and other economic activities.

Abadie and Gardeazabal (2003) study the indirect effects of ETA on the economy of the Basque region of Spain from the mid-1970s onward, when ETA significantly expanded its operations. They estimate what the Basque region's per capita GDP would be in the absence of terrorism. To do so, they create a "synthetic" region, a weighted composite region of the other regions of Spain (in terms of population and other key economic characteristics) which resembles the Basque region before the emergence of terrorism. This composite region is then compared to the actual Basque region. They find that the Basque region by the late 1990s was about 10 percent poorer than it would have been without terrorism. Abadie and Gardeazabal perform a number of robustness tests, including a "placebo" test in which they create a synthetic region that resembles Catalonia. This region, contrary to the composite Basque region, did not perform differently compared to the actual Catalonia region.

On another tack, Blomberg et al. (2004) take a macroeconomic perspective on the issue. In addition to terrorism, they also examine the effects of internal and external conflict on growth across 177 countries. They only consider transnational terrorist incidents, with the measures of internal conflict presumably being highly correlated with domestic terrorism. Through cross-country regressions they find the effect of terrorism to be statistically significant, but the quantitative effect is economically very small and smaller than those of internal or external conflicts. Furthermore, the

Footnote 13 continued

Another qualification typically provided, and which is followed by all the studies reviewed here, is that the organized groups are nonstate actors, even though, again, there is no scientific or policy reason that terrorist actions undertaken by governments should be excluded from consideration.

14 A direct cost estimate that includes the costs of destruction, cleanup, lost hours, and the values of lives lost on September 11, 2001, totals $\$ 48.7$ billion (Enders 2007). 
estimation of a structural VAR model showed that negative shocks to GDP due to internal or external conflicts yield much larger and longer-lived effects than those obtained from a negative shock due to terrorism. Blomberg et al. (2004) also find that terrorism has a strong negative impact on investment and a positive effect on government expenditures, thus providing a possible reason for the small economic effects of terrorism: That is, governments might consciously counteract the negative effects on investment by increasing expenditures. Nevertheless, it might be more plausible that increases in government expenditures are actually due to increased security expenditures in response to terrorism. This last possibility is corroborated by the fact that internal conflict induces higher government expenditures than terrorism does. Curiously, though, internal conflict does not appear to have the expected negative effect on investment in Blomberg et al.'s study.

The issue of terrorism's impact on investment—specifically foreign direct investment (FDI) - is picked up by Abadie and Gardeazabal (2008), who use a very different measure of terrorism than others. Following the criticism of Frey et al. (2007), who argued that measures of terrorism underestimate the number of incidents and casualties, Abadie and Gardeazabal use the World Markets Research Centre's Global Terrorism Index (GTI) as their terrorism variable. The GTI combines expert ratings at the country level and covers 186 countries and territories for the period 2003-2004 (World Markets Research Center 2003). Abadie and Gardeazabal estimate a statistically significant effect of terrorism on FDI that may be economically significant. Nevertheless, as Blomberg et al. (2004) suggest, such reductions in FDI may well not lead to lower growth because reduced investment may also be correlated with higher government expenditures. Furthermore, given that the GTI is compiled by country experts (typically not from the country being evaluated), the index may reflect not so much "terrorism" risk but the types of other risks that typically lead foreign investors to reduce investment in a country. That is, GTI might not be truly exogenous as far as its effect on FDI is concerned.

The estimated costs of terrorism are either very small or, as in the case of Spain's Basque region, of the order of 10 percent of GDP. That is considerably lower than the effects of either civil war or lower-level internal conflict. Moreover, as I have stressed, terrorism is a tactic and not an altogether different type of conflict. ETA's campaign used terrorist tactics but also, I suspect, the Basque region had more strikes, protests, and other manifestations of lower-level conflicts than other regions of Spain had. That is, the difficulty of finding strong effects of terrorism could be due to the fact that it is inherently difficult to isolate terrorism's effect from the broader context of conflict. When terrorist tactics are isolated from broader internal conflicts, as in the case of richer countries (with exceptions like those of the Basque region), the effects are negligible. When terrorism is just one part of a larger internal conflict, as it usually is in low-income countries, the effects are stronger as they are correlated with these broader conflicts.

\subsection{External conflicts}

There have been considerably fewer external wars than internal wars since World War II, but the two types of war cannot be completely separated. After all, for much of 
this time a "Cold" war was taking place which fueled high military expenditures by the United States, the Soviet Union, and their respective allies. Moreover, from Vietnam and Cambodia to Angola and Nicaragua, some of the civil wars were at least partially or indirectly due to superpower rivalry, and the actions of proxies of the two superpowers were critical in the instigation or propagation of such wars. More recently, the war that has taken place in Zaire/the Democratic Republic of Congo, even though is typically classified as a civil war, has involved the active participation of the militaries of Rwanda, Uganda, Angola, Zimbabwe, Burundi, and Chad, while other countries, from Libya to South Africa provided considerable help to at least one of the many different sides that participated in that war (see Prunier 2009).

The most identifiable cost of partially external conflicts is military expenditures by governments. (Of course, as mentioned earlier, for many countries that have experienced internal wars, government military expenditures have not been directed towards external adversaries but domestic ones.) Such expenditures vary widely across different countries, rarely going below 1 percent of GDP. However, a few cases go above 10 percent of GDP, such as Saudi Arabia. In fact, for 1991 (and probably because of payments associated with the first Gulf War), Saudi Arabia's military expenditures went over 22 percent of GDP. Japan's military expenditures, on the other hand, have hovered around or just below 1 percent of GDP, although these expenditures have been large, consistently exceeding $\$ 40$ billion over the past decade. ${ }^{15}$ In 2004 world military spending was estimated to be over 1 trillion dollars, about 2.6 percent of world GDP (SIPRI 2005). Military spending data does not include some other defense expenditures on intelligence or on civilian research and development (R\&D) that is in practice military R\&D. ${ }^{16}$ Some evidence indicates that military spending has decreased from earlier decades. Knight et al. (1996) report that military spending in a sample of 122 countries averaged almost 5.2 percent of GDP for the 1972-1985 period.

A comprehensive accounting of the costs of an external war is offered by Stiglitz and Bilmes (2008), who estimate the cost of the Iraq war for the United States. Stiglitz and Bilmes do not calculate the costs to Iraq itself, though they do provide a considered qualitative assessment of what it costs Iraq to be the battleground of war. In their estimates, they include items such as the following: budgetary appropriations to date for military operations, and estimates for their future values, all appropriately discounted; future disability and health care for returning veterans; future costs of restoring the military to its prewar strength, replenishing spent armaments, repairing equipment where maintenance has been deferred; estimates of some costs to the economy (for example, in some scenarios, they allow for $\$ 5$ and $\$ 10$ increases in the price per barrel of oil to be attributed to the war); other macroeconomic effects, like the possible crowding out of some investment expenditures. Overall, Stiglitz and Bilmes

\footnotetext{
15 Note that, according to the Stockholm International Peace Research Institute (SIPRI), Japan's Constitution prohibits a military and, thus, these are formally considered "police" or "internal security" expenditures.

16 However, some military R\&D expenditures have direct civilian applications or are disguised civilian R\&D. In fact, many major breakthroughs in technology - the Internet, various high-tech materials, computers, shipbuilding - have their roots in military R\&D. One could possibly argue, then, that military spending is worth it just for the tremendous technological benefits it has afforded nations. However, it must be asked why one should spend money on military R\&D in the hope of receiving some future uncertain technological benefits rather than directly investing in $R \& D$ for targeted civilian applications.
} 
estimate that the total cost of the war ranges from $\$ 2.7$ trillion in strictly budgetary costs to $\$ 5$ trillion in total economic costs.

Other than this recent work, there appears to be a relative scarcity of studies that estimate the long-term costs of external wars. Blomberg et al. (2004), Blomberg and Hess (2010) do so only parenthetically as they examine the effects of other types of conflict, though they both find that external wars negatively impact growth. ${ }^{17}$

However, an older literature regarding the effects of military expenditures on economic growth has found positive effects, presumably due to short-run demand effects or long-run technological externality effects. I will not review this literature here, but Knight et al. (1996) provide an overview and find negative effects on growth. Moreover, as Dunne et al. (2005) point out, such empirical studies are hampered by the fact that they are based on either defense-economics models or expanded endogenous growth models that emphasize the possible technological externalities of military expenditures without taking adequate account of the resource cost of these expenditures. Moreover, apparently in none of these empirical approaches is the possibility that military expenditures are determined strategically (that is, in reaction to potential adversaries).

\subsection{Overview of costs}

I am aware of just one study that attempts a comprehensive estimate of the costs of conflict from many different sources: Blomberg and Hess (2010). ${ }^{18}$ Blomberg and Hess adapt a model of Lucas (1987) that was meant to measure the costs of business cycles and uses it to estimate the impact of conflict, regarded as a "shock", to consumption and welfare. No direct or indirect costs are calculated or estimated. Instead, Blomberg and Hess compare the expected welfare of each country's actual path of consumption - that may include conflict - to another counterfactual path of consumption where there is no state of war. Using data from 1960 to 1992, someone living in a county that experienced some conflict would permanently give up at least 8 percent of current consumption to live in a peaceful world; this figure is calculated by Blomberg and Hess as a lower bound of the true welfare cost of conflict. Naturally, there is wide variation across countries. All high-income countries included in the study (Australia, Canada, France, Italy, the United Kingdom, and the United States) have considerably lower costs of consumption as a percentage of consumption (with France and the United States topping the list with just over 3 percent of their consumption), but still high costs in absolute terms. Most African countries have higher costs than average, with Angola's cost being over 40 percent of annual consumption. Iraq tops the list with a cost of 65 percent of its annual consumption, while Iran's cost is 26 percent-both high levels are due to the war fought by these two countries in the 1980 s.

\footnotetext{
17 Furthermore, wars are correlated with less trade (Seiglie 2008) and lower foreign direct investment (Busse and Heffeker 2007, as well as Abadie and Gardeazabal 2008, mentioned earlier). However, at least for the case of trade and possibly for the case of FDI, disentangling the causal direction is not easy.

18 The study examines four types of external wars in terms of whether they were at home or not, and whether they were "small" or "large." Internal wars are subdivided into genocides, ethnic conflicts, abrupt and disruptive regime changes, and revolutionary wars.
} 
The lower bound of the total world cost of conflict in 1985 dollars is estimated by Blomberg and Hess to be close to $\$ 400$ billion to be paid every year, with that payment growing at the rate of population growth. Given Collier et al. (2008) lowerbound estimate for the yearly cost of civil wars alone- $\$ 123$ billion (in, presumably, 2008 dollars), and an average estimate of close to $\$ 500$ billion-Blomberg and Hess's lower-bound estimate for all types of conflicts appears reasonable. Therefore, without even counting the extra military expenditures of the Unites States during the twenty first century, an overall annual cost of $\$ 1$ trillion for organized violence should be considered a low-end estimate. Taking into account military expenditures and other direct and indirect effects of conflict and violence would result in considerably higher cost estimates.

The Blomberg and Hess (2010) apporach, because it tries to estimate the "welfare" cost conflict, is complementary to Frey et al. (2007) approach. Frey et. al. use a life satisfaction approach, in which individual utility is approximated by self-reported subjective well-being, and they find that losses from conflict (terrorism, in the case of the particular paper) may far exceed the purely economic consequences. This is similar to the finding about the inordinate welfare cost of unemployment that goes well beyond the monetary losses brought about unemployment (see, e.g., Layard 2005), and it is worth pursuing further as a research question.

\section{Open issues and future directions}

Economists have only recently been interested in the costs of conflict and violence as a legitimate policy concern and as an endeavor worthy of study. With the exception of the literature that relates military expenditures to economic growth, virtually all research on the costs of conflict and violence has occurred over the past decade. Already, though, the literature has grown extensively, and, if anything, the pace of research is gaining speed, especially research on civil war. The increasing interest is obviously warranted given that the costs of conflict and violence are quantitatively very significant, arguably more significant than any other measured economic costs that might be relevant to economic development.

Some direct costs are easily measurable, such as those due to destruction or increased government spending. However, most costs, even direct ones such as those associated with death and injury, are not easy to estimate, let alone indirect costs that might result from lower investment, capital flight, or reduced tourism. Such estimates are based on either deterministic scenarios or stochastic models that are econometrically estimated, the latter of which often suffer from small samples or even data of questionable provenance. Researchers and policymakers are unlikely to agree on the relevance or appropriateness of particular scenarios or models and, therefore, on the estimated costs derived from them. It is healthy, even vital, to consider a wide range of opinions and methodologies - such diversity is often key to arriving at well-rounded estimates. In some cases, general agreement might be unattainable simply because there are too many disagreements about processes or causal mechanisms. Finally, the personal views of those involved may significantly affect the evaluation of a particular consequence of conflict. 
I will now briefly discuss remaining issues and future directions for measuring and estimating costs associated with the four types of conflict reviewed. I will close with general remarks on assessing the costs of conflict.

\subsection{Civil wars}

As is apparent from the work reviewed here, civil wars have received the lion's share of researchers' attention. Such attention seems warranted when one considers the large number of civil wars in the post-war period, and the accompanying high human and economic costs. Detailed studies of country experiences along with comparative assessments, such as those discussed in Stewart and Fitzgerald (2001), are helpful complements to econometric studies that rely on more aggregated data. In particular, it is encouraging to witness recent trends in microbased studies, such as those of Bellows and Miguel (2008) or Blattman (2008), which follow samples of war-affected soldiers or individuals involved to determine both the individual and community consequences of war. Such approaches already challenge some of our preconceptions of the effects of war on individuals and their communities (or, "social capital") and additional studies are needed to clarify those effects. Are former victims of violence truly better adjusted because of self-selection-in the sense that those who are poorly adjusted might be more likely to die or be excluded from studies-or have war experiences truly galvanized them to become civically engaged?

Collier et al. (2003) have emphasized the possible negative impact civil wars have on social capital and trust-and, in turn, on economic growth. They do not provide, however, much evidence to support that negative relationship. Therefore, operationalizing notions of social capital (or, of governance and institutions) in various settings and examining its relationship to both the direction of civil war and economic growth is certainly a worthy avenue for future research. Recent theoretical work by McBride et al. (2010) show how expenditures on governance is related to income and feeds back into the likelihood of peace. The effect of civil wars on poverty and inequality, and the costs associated with them, are also of obvious continued interest.

Another quantitatively important effect emphasized by Collier et al. (2003); Collier et al. (2008) is the spillover effect of war on neighboring countries, following on the work of Murdoch and Sandler (2002), who appear to have made the sole estimates of such spillover effects. Finally, the expected effect of internal wars and other types of conflict on investment and capital flight does not always appear as statistically or economically significant (for example, see Blomberg et al. 2004). Since this effect is expected to be one of the key channels through which wars negatively impinge economic growth, it is important to continue investigating the relationship both in country and comparative studies.

\subsection{Lower-level internal conflicts}

As argued by Sambanis (2004), the particular definition of civil war adopted in any cross-country comparison can significantly change the results. This is indicative of the fact that civil wars are not completely distinct from all other types of internal 
(or external) conflict. Rather, there is a continuum of conflict intensities that might include, say, the Democratic Republic of Congo and Rwanda on one end of the spectrum, and the myriad of internal conflicts that involve minimal violence or the threat of violence (such as strikes or road blockades) on the other. The middle and lower ends of the spectrum have been understudied, and severely so when compared to the study of civil wars.

Examples of such violence abound. In addition to the war in Aceh province, violence has been endemic over at least the past decade to Indonesia, from the Mollucas to Borneo and Irian Jaya, to Javanese villages and towns. Furthermore, the motives of this violence have been difficult to decipher. (They can be characterized as overtly religious, ethnic, economic, or regional, but one must be careful about what appears as overt.) Similarly, conflict has been continual in Nigeria's delta since the Biafra war, and recently has flared up with consequences for oil production there. In Brazil and other Latin American countries, there are systematic disputes over land rights, pitting large landowners against organized unions of squatters. These sometimes involve deadly clashes of private security forces and union members. Some of these disputes can be considered economic, as they focus on the disposition of revenues from exportable natural resources. They have been studied as such under the rubric of the "natural resource curse". ${ }^{19}$ Nevertheless, there has been no effort to systematically create databases that classify and measure aspects of these softer types of internal conflicts as there has been for civil wars. Yet, given the limited evidence obtained thus far, the long-term costs of such conflicts could well be of a similar order of magnitude to those of civil wars. It is highly advisable, then, to collect evidence at both the micro and macro levels, as has been done in research on civil wars.

\subsection{Terrorism}

Since terrorism is correlated with other types of conflict, it is difficult to isolate the effects of the tactic itself from the wider conflict to which it might be a part. Future studies would find value in pursuing the approach of Blomberg et al. (2004), who include in regressions other types of conflict to tease out substitution or complementary effects.

\subsection{External conflicts}

A major unresolved issue that pertains to the costs of external wars is that of the relationship between military expenditures and economic growth. As we mentioned above, the main problem is disentangling the negative effect of military spending that results from the reduction of resources that become unavailable for consumption or investment - and any distortions that might be associated with these-from the possible positive effects of military spending that results because output is below its potential level or that results from technological and organizational externality effects to the

\footnotetext{
19 See for example Ross (2003), Mehlum et al. (2006).
} 
rest of the economy. It appears that all of the models thus estimated do not adequately take into account the resource cost of military expenditures. They especially fail to take into account the endogeneity of expenditures to those of other countries or to the choices of internal potential enemies (to the extent that some countries direct their military expenditures against such enemies). ${ }^{20}$ It is therefore advisable to account for how strategic feedback affects security and military expenditures when studying their effect on economic growth.

Furthermore, the related literature has relied solely on cross-country evidence using aggregated data (for example, GDP, investment, military expenditures, and other aggregate variables). More detailed country case studies could break down the various components of military expenditures, investment, and other variables. Institutional knowledge of a country's economy and government should not be ignored when making assessments about the composition of these components, their relationship to each other, and to economic growth.

\subsection{Adding up the costs of organized violence}

I am not aware of any attempt to add up all the types of organized violence costs that are reviewed in this paper. Blomberg and Hess (2010) comes closest, but as discussed earlier, this approach is highly indirect and "top-down" in that the authors estimate, using a cross-country econometric framework, the effects of the "shock" of conflict on consumption. Whereas this is a valuable approach that has produced plausible estimates (and expanding and refining Blomberg and Hess's approach would be most welcome), there is scope in also pursuing a "bottom-up" approach, whereby direct and indirect costs of the various types of organized violence are estimated and tabulated for individual countries and for the whole world. Collier et al. (2008) do provide overall estimates for the cost of civil wars, but there is no documentation in that paper on how these estimates were derived. Having both bottom-up and top-down estimates of the total costs of organized violence would help check the plausibility of the other mechanism. If the estimates do not vary too widely from one another, one can have high confidence in them.

A fundamental issue of concern to economists and policymakers must be mentioned here, though unfortunately not in appreciable detail. ${ }^{21}$ An argument could be made that at least some of the costs of war and violence are necessary, as they could be considered the costs of "enforcing property rights" by states or other organized interests. Military expenditures and other security costs, even possibly the very destruction that ensues from the outbreak of wars, could be considered a necessary input into an output called "security." Therefore, from a social welfare perspective, these may not be considered avoidable (without incurring other costs at some point). A very short response to this suggestion would first point out that, contrary to other inputs in

\footnotetext{
20 Models that do take into account this endogeneity include Hirshleifer (1995), Grossman and Kim (2006), and others reviewed in Garfinkel and Skaperdas (2007).

21 For a detailed theoretical treatment of related issues, see Skaperdas (2008) and the overview of Garfinkel and Skaperdas (2007).
} 
economics, the inputs to conflict and violence are combined in an adversarial fashion, not cooperatively as are inputs to ordinary production. Secondly, military increases by one party that are met with similar increases by another would increase the costs of security to both parties without necessarily changing the security of either, however that latter is measured. (On the contrary, the military build-up could make war more likely, and, as a result, decrease the security of both.) Whereas the response of states and other organized groups could indeed be considered individually rational in the short term, it does not imply that the resulting state of affairs is socially rational. The outcome is similar to that of the prisoners' dilemma: if each side could commit to their actions, they could achieve a better outcome for both. Furthermore, economists routinely calculate the costs of socially suboptimal actions (such as those of trade protection) in other settings, where the actual policies are compared to ideal policies. Likewise, then, we can think of the costs of organized violence as due to deviations of actual security policies that are suboptimal from an ideal world. What is also different from other settings, however, is the possibility that in the actual world, the costs of providing security may increase dramatically while the benefits derived from it are drastically reduced, as is the case in wars that escalate beyond the original expectations of their participants.

Acknowledgments Stergios Skaperdas would like to thank Alexandre Marc, Gary Milante, Stephen Miller, anonymous referees for discussions or comments, and Nathan Fiala for research assistance.

Open Access This article is distributed under the terms of the Creative Commons Attribution Noncommercial License which permits any noncommercial use, distribution, and reproduction in any medium, provided the original author(s) and source are credited.

\section{References}

Abadie A, Gardeazabal J (2003) The economic costs of conflict: a case study for the basque country. Am Econ Rev 93(1):113-132

Abadie A, Gardeazabal J (2008) Terrorism and the world economy. Eur Econ Rev 57:1-27

Asmundo A, Lisciandra M (2008) The cost of protection racket in sicily. Global Crime 9(3):221-240

Bellows J, Miguel E (2008) War and local collective action in sierra leone. Unpublished working paper

Bilmes L, Stiglitz J (2006) The economic costs of the iraq war: an appraisal three years after the beginning of the conflict. National bureau of economic research working paper 12054, Cambridge, MA

Blattman C (2008) From violence to voting: war and political participation in Uganda. Center for global development working paper number 138, January

Blattman C, Miguel E (2010) Civil war. J Econ Lit 48:3-57

Blomberg BS, Hess GD (2010) The economic welfare cost of conflict: an empirical assessment, prepared for inclusion. In: Garfinkel MR, Skaperdas S (eds) The Oxford handbook of the economics of peace and conflict

Blomberg BS, Hess GD, Athanasios O (2004) The macroeconomic consequences of terrorism. J Monet Econ 51:1007-1032

Bruck T (2001) Mozambique: the economic effects of the war. In: Stewart F, Fitzgerald V (eds) War and underdevelopment, vol 2. Oxford University Press, Oxford

Busse M, Heffeker C (2007) Political risk, institutions, and foreign direct investment. Eur J Polit Econ 23(2):397-515

Cerra V, Saxena SC (2008) Growth dynamics: the myth of economic recovery. Am Econ Rev 98(1):439-457

Collier P (1999) On the economic consequences of civil war. Oxf Econ Pap 51:168-183

Collier P, Chauvet L, Hegre H (2008) The security challenge in conflict-prone countries. Prepared for Copenhagen consensus 2008 challenge conference, April 
Collier P, Elliott VL, Hegre H, Hoeffler A, Reynal-Querol M, Sambanis N (2003) Breaking the conflict trap: civil war and development policy. World Bank and Oxford University Press, Washington

Dunne JP, Smith R, Willenbockel D (2005) Models of military expenditure and growth: a critical review. Def Peace Econ 16(6):449-461

Enders W (2007) Terrorism: an empirical analysis. In: Sandler T, Hartley K (eds) Handbook of defense economics. North-Holland, New York, pp 815-868

Evia JL, Laserna R, Skaperdas S (2008) Socio-political conflict and economic performance in Bolivia. CESifo working paper, March

Fearon JD, Laitin DD (2003) Ethnicity, insurgency, and civil war. Am Polit Sci Rev 97:75-90

Fitzgerald V, Grigsby A (2001) Nicaragua: the political economy of social reform and armed conflict. In: Stewart F, Fitzgerald V (eds) War and underdevelopment, vol 2. Oxford University Press, Oxford

Fitzgerald V, Stewart F, Wang M (2001) An overview of the case studies. In: Stewart F, Fitzgerald V (eds) War and underdevelopment, vol 2. Oxford University Press, Oxford

Frey BS, Simon L, Stutzer A (2007) Calculating tragedy: assessing the costs of terrorism. J Econ Surv 21(1): $1-24$

Gardeazabal J (2010) Methods for measuring aggregate costs of conflict, prepared for inclusion. In: Garfinkel MR, Skaperdas S (eds) The oxford handbook of the economics of peace and conflict

Garfinkel MR, Jeliazkov I (2004) Comment on the macroeconomic consequences of terrorism. J Monet Econ 51:1033-1037

Garfinkel MR, Skaperdas S (2007) Economics of conflict: an overview. In: Sandler T, Hartley K (eds) Handbook of defense economics. North-Holland, New York, pp 649-709

Ghobarah HA, Paul H, Russett B (2003) Civil wars kill and maim people-long after the shooting stops. Am Polit Sci Rev 97(2):189-202

Glenny M (2008) McMafia: a journey through the criminal underworld. Alfred A. Knopf, New York

Gonzalez FM (2010) The use of coercion in society: insecure property rights, conflict and economic backwardness, prepared for inclusion. In: Garfinkel MR, Skaperdas S (eds) The Oxford handbook of the economics of peace and conflict

Grossman HI, Kim M (2006) Predation and accumulation. J Econ Growth 1:333-351

Hirshleifer J (1995) Anarchy and its breakdown. J Polit Econ 103:26-52

Justino P (2006) On the links between violent conflict and chronic poverty: how much do we really know? Households in conflict network working paper 18, July

Justino P (2010) War and poverty, prepared for inclusion. In: Garfinkel MR, Skaperdas S (eds) The Oxford handbook of the economics of peace and conflict

Knight M, Loayza N, Villanueva D (1996) The peace dividend: Military spending cuts and economic growth. IMF Staff Pap 43:1-37

Layard R (2005) Happiness: lessons from a new science. Penguin, New York

Lucas RE Jr (1987) Models of business cycles. Basil Blackwell, New York

Mardsen P, Samman E (2001) Afghanistan: the economic and social impact of conflict. In: Stewart F, Fitzgerald V (eds) War and underdevelopment vol 2. Oxford University Press, Oxford

McBride M, Milante G, Skaperdas S (2010) Peace and war with endogenous state capacity. University of California, Irvine Economics Deparment

Mehlum H, Moene K, Torvik R (2006) Institutions and the resource curse. Econ J 116:1-20

Merrouche O (2008) Landmines and poverty: IV evidence from mozambique. Peace Econ Peace Sci Public Policy 4(1)

Miguel E, Roland G (2006) The long run impact of bombing vietnam. National bureau of economic research working paper 11594, Cambridge, MA

Miguel E, Satyanath S, Sergenti E (2004) Economic shocks and civil conflict: an instrumental variables approach. J Polit Econ 112(4):725-753

Murdoch JC, Sandler T (2002) Economic growth, civil wars, and spatial spillovers. J Conflict Resolut 46(1):91-110

O'Sullivan M (2001) Sri Lanka: civil strife, civil society, and the state 1983-1995, chap 7. In: War and underdevelopment, vol 1. Oxford University Press, Oxford

Prunier G (2009) Africa's world war: Congo, the rwandan genocide, and the making of a continental catastrophe. Oxford University Press, Oxford

Riascos AJ, Vargas J (2004) Violence and growth in Columbia: what do we know after 10 years of quantitative research? Upublished working paper 
Ross M (2003) The natural resource curse: how wealth can make you poor. In: Bannon I, Collier P (eds) Natural resources and violent conflict: options and actions. World Bank, Washington

Sambanis N (2004) What is civil war? Conceptual and empirical complexities of an empirical definition. J Conflict Resolut 48(6):815-858

Sandler T, Enders W (2008) Economic consequences of terrorism in developed and developing economics. Unpublished working paper

Seiglie C (2008) Openness of the economy, terms of trade, and arms. Rutgers University, Newark

Skaperdas S (2001) The political economy of organized crime: providing protection when the state does not. Econ Governance 2:173-202

Skaperdas S (2008) Economics and conflict: the dark side of self-interest and its governance as economic activities

Stewart F, Fitzgerald V (eds) (2001) War and underdevelopment vol 2. Oxford University Press, Oxford

Stewart F, Huang C, Wang M (2001) Internal wars in developing countries: an empirical overview of economic and social consequences. In: War and underdevelopment vol 1. Oxford University Press, Oxford

Stiglitz JE, Bilmes LJ (2008) The three trillion dollar war: the true cost of the iraq conflict. W.W. Norton and Co, New York

Stockholm International Peace Research Institute (SIPRI) (2005) 2005 Yearbook armaments, disarmament and international security. Stockholm International Peace Research Institute, Stockholm

United Nations High Commission for Refugees (UNHCR) (2007) 2006 Global trends: refugees, asylum seekers, returnees, internally displaced persons, and stateless persons. United Nations High Commission for Refugees, Geneva. http://www.unhcr.org/statistics/STATISTICS/4676a71d4.pdf 